\title{
THE RISE IN LIFETIME EARNINGS INEQUALITY AMONG MEN
}

\author{
Stephanie Aaronson*
}

This version: March 2002

First version: April 2000

\begin{abstract}
Recent trends in lifetime earnings inequality in the United States have been barely explored, despite the fact that lifetime earnings are a better measure of access to resources than the more widely studied annual earnings. This paper demonstrates that lifetime earnings inequality has increased over the past 30 years. We first explore how starting wages and wage growth have changed over time and link the changes to trends in lifetime earnings and the lifetime skill-premium. We then calculated a broader measure of lifetime earnings inequality and show that since the late 1960s, lifetime earnings inequality has increased by a third. Between the late 1960s and mid-1970s a rise in within-education-group inequality more than accounts for the increase; since then the growth in between-educationgroup inequality, accounted for a majority of the rise. These results are consonant with the data on starting wages and wage growth. Finally, we show that the increase in inequality has been largely driven by greater dispersion in hourly wages, although declining hours of work among low-education young men did play a role. The analysis uses data from the March Current Population Survey as well as matched CPS data. Thus we demonstrate how repeated cross-sections and short panels of data can be used to examine issues usually reserved for long panels.
\end{abstract}

\footnotetext{
*Board of Governors of the Federal Reserve System, e-mail: Stephanie.R.Aaronson@frb.gov. The author would like the thank Deborah Aaronson, Stephen Cameron, Bruce Fallick, Andrew Figura, Michael Palumbo, Brendan O'Flaherty, Joseph Tracy, and William Wascher for helpful comments. The views presented are solely those of the authors and do not necessarily represent those of the Federal Reserve Board or its staff.
} 


\section{Introduction}

Numerous authors have documented and sought to explain the growth in annual earnings inequality that has occurred over the last 30 years in the United States (cf. Levy and Murnane, 1992 and papers cited therein). In contrast, little attention has been paid to whether lifetime earnings inequality has also increased. This is a significant omission. Lifetime earnings inequality is a better measure of the disparate access to resources across individuals than crosssectional inequality, since differences in individual earnings at a point in time may be transitory and offset at other points in time. ${ }^{1}$ Moreover, it is not possible to disentangle permanent and transitory differences in earnings from a cross-section of data. As has been previously shown (cf. Shorrocks, 1978), lifetime inequality is only equal to cross-sectional inequality under stringent conditions that are unlikely to be met.

The goal of this paper is to fill the gap in the existing literature by exploring recent trends in both the level of lifetime earnings and lifetime earnings inequality. We begin by presenting evidence on how real wage growth, an important determinant of lifetime earnings, has changed over time and discuss some preliminary evidence on changes in lifetime earnings add the lifetime skill premium. We then calculate a measure of lifetime earnings inequality and decompose the change in inequality into a between-education-group component, which captures changes in wage growth, and a within-education group component. The paper also examines whether trends in lifetime earnings have been driven by variation in the distribution of hourly wages or in the distribution of hours of work. The analysis relies on artificial cohorts drawn from the 1968 to 2000 March Demographic Supplements to the Current Population Survey

\footnotetext{
1 Lillard (1977) gives an early statement of the importance of examining lifetime earnings, what he called human wealth.
} 
(CPS) and on a less commonly used data set: 25 panels of the matched CPS, which follow a given individual over two years. $^{2}$

The paper presents 4 main findings. First, between the late $1960 \mathrm{~s}$ and the late $1980 \mathrm{~s}$ starting real wages for young men entering the labor market declined within all education groups, but particularly for low-education workers. Losses range from 7 percent for college graduates to 20 percent for high school graduates. ${ }^{3}$ Second, while college graduates have been able to make up for declining starting wages with higher real wage growth, workers with less education have not. Among college graduates, real wage growth increased from 44 percent over the first ten years of the career for cohorts that started working in the late 1960s to 65 percent for those who entered the labor market in the late 1980s. In contrast ten-year real wage growth among high school drop-outs declined from nearly sixty percent among the late 1960s cohort to less than 40 percent among the late 1980s cohort. Thus for the late 1960s cohorts, real wage growth ameliorated differences in starting wages across workers with different levels of education, whereas for young men who started working in the late 1980s, real wage growth exacerbated differences in starting wages.

\footnotetext{
${ }^{2}$ Although the paper refers to lifetime earnings inequality, what is actually measured is inequality over the first ten years of the career. However, evidence suggests that inequality measured over the first ten years of the career is likely to be a good measure of lifetime inequality and as such it is not misnamed. Examining the 1960s and 1970s cohorts, we find that the increase in earnings inequality across these cohorts over the first 20 years of their careers is the same as the increase in earnings inequality over the first ten years. This finding is unsurprising given the fact that most wage growth takes place over in the first ten years of the career. Of the 12 cohorts observed in the CPS for 20 years, total wage growth between the 10th and 20th year never exceeded 12 percent and could be as low as 6 percent. Murphy and Welch (1990) find that approximately 80 percent of lifetime wage growth occurs in the first ten years of the career. Thus there is less chance for low wage individuals to catch up through higher wage growth at these later ages. Moreover, analysis of the CPS data does not indicate that low-education workers experience more wage growth in the later years than high-education workers. Thus it appears that not much would be gained by using a longer time frame, while such a requirement would eliminate recent cohorts of workers.

3 Starting wages refer to the average wage earned by a young man in his first year out of school. The CPS does not include information on a worker's first job.
} 
Third, as might be suspected from the changing patterns of wage growth, lifetime earnings have declined for all but the most highly educated workers and inequality has increased: the college/high school graduate ten-year earnings premium was nearly one-third higher for the late 1980s cohorts than for the late 1960s cohorts and the coefficient of variation increased by one-third. About 35 percent of the increase in inequality can be attributed to an increase in between-education-group inequality and 65 percent can be attributed to within-group changes. The largest increase in within-education-group inequality occurred in the 1970s, while the increase in between-education-group inequality was the driving force behind increases in lifetime earnings inequality during the 1980s. Finally, the decline in lifetime earnings and the increase in lifetime earnings inequality has been largely driven by changes in the distribution of hourly wages, although between the late 1960s and early 1970s a reduction in annual hours worked explains all of the decline in lifetime earnings for high school drop-outs and two-thirds of the decline in lifetime earnings for workers with a high school degree, increasing betweengroup inequality during this period.

Overall our findings suggest that more recent cohorts of low-skilled young men have significantly lower lifetime earnings both relative to their peers in early cohorts and compared to higher-skilled men in their own cohort. These trends in lifetime earnings have important implications for decisions that depend on access to economic resources, such as family formation, home ownership and retirement. These findings also contribute to our understanding of the labor market over time. The fact that lifetime inequality has increased within education groups supports the theory (cf. Juhn et al., 1993) that the increase in cross-sectional withineducation group inequality is due to persistent factors such as increased returns to unmeasured ability rather than transitory shocks (see also Haider, 2001 on this point). 


\section{Summary of the Literature}

The empirical literature on lifetime earnings inequality in the United States is not very extensive. Early examples include Lillard (1977) and Parsons (1978), both of whom examined single cohorts of workers. Two recent studies have investigated changes in long-run inequality over time. Gittleman and Joyce (1996) focus on how short-term mobility and 5-year earnings inequality have changed over time and across different skill and education groups. Haider (2001) analyzes changes in earnings instability and lifetime earnings inequality in order to disentangle possible explanations for the increase in cross-sectional earnings inequality. In addition a large number of studies have examined the related issue of economic mobility over at least part of the same time period (cf. Buchinsky and Hunt, 1996; Gittleman and Joyce, 1995; Moffitt and Gottschalk, 1993; Hungerford, 1993).

This study differs from the existing literature in several ways. First, our study focuses on workers in their first ten years after leaving school, whereas previous work has concentrated on men over the age of 25. However, since most wage growth takes place in the first ten years of the career, eliminating young workers obscures the story. In particular, we are unable to observe the early years of work for low-education workers in such a sample, and instead compare college graduates with only a few years of work experience with individuals with a high school degree or less who have been working between 6 and 8 years.

Second, we present an array of findings not covered in the previous literature. We discuss changes in the wage determination process, particularly in starting wages and returns to experience, which underlie the changes in lifetime earnings and earnings inequality. Then with respect to lifetime earnings inequality itself, we present findings on the relative importance of changes in between- and within-education group lifetime inequality and changes in the 
distribution of wages and hours of work in generating the observed trends in lifetime earnings inequality. These results are useful for understanding the forces driving the change in the distribution of lifetime earnings that we observe. Haider does examine how changes in the permanent and temporary components of wages and hours of work contribute to annual income inequality, but does not specifically examine them in the context of lifetime earnings inequality.

Third, our measure of lifetime earnings inequality is based on actual changes in the distribution of earnings of successive cohorts. In contrast, Haider (2001) measures lifetime earnings inequality based on the assumptions that the returns to experience that appear in the cross-section in a given year are the same returns faced by an individual over his or her lifetime. However, given the changes in cohort wage profiles we discuss below, these assumptions are unlikely to be true. ${ }^{4}$ To calculate long-run inequality Gittleman and Joyce (1996) use a method similar to that employed here. However, they group together individuals in broad experience bands of up to ten years that they are less easily identified with specific cohorts of workers and they follow them for only 5 years.

Finally, this paper also makes a methodological contribution, by demonstrating how repeated cross-sections and short panels of data can be used to examine issues usually reserved for long panel surveys. This is useful because a number of very rich data sets are cross-sections, or comprise only short panels, such as the such as the Consumer Expenditure Survey and the Survey of Consumer Finance.

\footnotetext{
4 Haider's approach does allow him to estimate a rich specification of the earnings process, and to link earnings instability and lifetime earnings inequality more closely than we do here.
} 


\section{Data}

\subsection{The Whys and Hows of Synthetic Cohort Analysis}

Rather than using panel data to perform a study of lifetime earnings, we use data on synthetic cohorts, created from the 1968 through 2000 Annual Demographic Supplements to the Current Population Survey (CPS) and 2-year panels of matched March CPS data. ${ }^{5}$ For synthetic cohort analysis, one does not need to observe the same individuals over time. It is enough to simply observe a representative sample of individuals with the same characteristics over time as we do in the CPS. ${ }^{6}$ There are two advantages to using the CPS rather than the available panel data. Most importantly, the CPS provides large samples allowing for the analysis of detailed subgroups of the population---in this case individuals by level of education and single year of labor market experience. ${ }^{7}$ Another advantage of the CPS is that there is a long time-series, allowing us to track the synthetic cohorts over an extended period of time. ${ }^{8}$

\footnotetext{
5 Although the CPS is most often used as cross-sectional data, the sampling structure allows for the creation of 2 year panels. Half of the individuals surveyed in a given March are scheduled to be re-surveyed in the following March, creating the possibility of matching individuals over time. Ultimately the matched sample has fewer than half the observations of the regular CPS since some individuals cannot be matched either because they move or because there is insufficient data. A brief discussion of the matched CPS is included in the data appendix. See Peracchi and Welch (1995) for a more detailed discussion of the matched CPS.

6 The primary limitation of the CPS in this respect is that it does not consistently allow us to eliminate immigrants from the sample. Therefore the cohorts may change somewhat over time due to immigration. However evidence presented in Borjas, Freeman, and Katz (1997), based on the Decennial Censuses and the CPS, indicates that excluding non-natives from the sample would not significantly change the education wage premiums nor the trend in the premiums over time.

7 Gottschalk and Moffitt (1992) note that the sample of prime age white men with earnings data is about 10 times higher in the CPS than in the PSID.

${ }^{8}$ The time dimension is a particular advantage of the CPS over the National Longitudinal Surveys.
} 


\subsection{Sample selection and variable construction}

The sample selection and the construction of variables is the same for both the matched and unmatched CPS. Here we provide a brief description of the how the data is processed; additional details on a few topics are provided in the data appendix. Individuals are assigned to cohorts based on year of entry into the labor market and level of education (high school dropout, high school graduate, some college, or college graduate). In order to increase the sample size and simplify the presentation of results, cohorts based on single years of entry into the labor market are combined into six broader cohorts, each consisting of four entry years beginning with the 1967-1970 cohorts and ending with the 1987-1990 cohorts. The average sample size of each cohort group by level of education can be found in Table $1 .{ }^{9}$

The sample is restricted to men with one to ten years of potential experience who are not in school, retired, or in the armed forces at the time of the interview and who did not list being in school or retired as a reason for working less than full-time in the year prior to the survey. Potential experience is calculated as min(age-education-7, age-17). Individuals with imputed income data are deleted from the sample as are individuals with over $\$ 100$ in either selfemployment or farm earnings. ${ }^{10}$ To be included in the matched data set, an individual has to meet these criteria in both survey years. Sample weights are not used.

The primary variable of concern is annual wage and salary income in the calendar year

\footnotetext{
9 The sample sizes from the matched CPS are considerably lower than for the unmatched sample. This reflects the smaller sample size of the matched data relative to the full CPS (see footnote 4), the fact that individuals in the matched sample must meet the sample criteria in both years, and finally, the fact that in some pairs of years, individuals cannot be matched over time (see data appendix).

10 Using imputed data to calculate covariances of earnings across time would generate noise. For a detailed analysis of imputation in the census and particularly the CPS see Lillard et al., 1986. Note that the article does not describe the changes made to the imputation procedure beginning in 1989.
} 
prior to the survey. People who have no wage and salary earnings are included in the sample because the increase in nonwork has certainly affected lifetime earnings. The data are deflated to 1999 dollars using the Personal Consumption Expenditure deflator. ${ }^{11}$

Individuals with top-coded income are eliminated from the sample. ${ }^{12}$ As we concern ourselves with younger workers, this results in trimming an average of 0.6 percent of our sample in each year. Evidence suggests that the top-coding in the CPS results in an underestimate of the increase in cross-sectional inequality over time (cf. Bishop et al., 1994; Fichtenbaum and Shahidi, 1988). Because the variance of cross-sectional earnings is a component of the variance of lifetime earnings, the increase in lifetime inequality identified here should be viewed as a lower bound.

In the final section of the paper we make use of data on annual hours of work, which is calculated as the number of weeks worked per year multiplied by the usual hours worked per week. The CPS did not begin to measure usual hours worked per week in the year prior to the interview until 1976. Therefore it was necessary to impute these data. ${ }^{13}$ Also prior to 1976, data on weeks worked in the year prior to the interview were reported in intervals. Therefore, individuals have been assigned to an actual number of weeks worked using information on the relationship between the complete distribution of the weeks worked variable in the post-1976

\footnotetext{
${ }^{11}$ The path of real wages is similar when either the Personal Consumption Expenditure (PCE) deflator or the CPI-XI is used as a deflator. Using the unadjusted CPI results in a much steeper decline in real wages. Real wages deflated with the GDP deflator follow a path similar to that of wages deflated with the PCE until the late 1980s when they begin to decline less steeply.

12 A common solution to the top-coding problem (cf. Bishop et al., 1994; Fichtenbaum and Shahidi) is to estimate the mean of the tail of the distribution above the top-code based on the assumption that it can be reasonably approximated by a pareto distribution, and then to assign this value to individuals with top-coded earnings. This approach is not appropriate for our purposes since it involves imputing the earnings of these individuals, rendering the data unsuitable for use in calculating the covariance of earnings across the two years.

13 The hours of work imputation is based on a program provided by Chinhui Juhn.
} 
data and other variables. Both procedures are described more fully in the data appendix.

Comparison of the imputed hours and weeks data to the actual data available in the 1976 to 2000 surveys shows little difference in the means or the trends.

The analysis in the last section of the paper also makes use of hourly wage data. The Annual Demographic Supplements do not contain a measure of the usual hourly wage. Therefore, it is calculated as annual wage and salary income divided by annual hours worked. This results in some implausible values for hourly wages. In the analysis making use of the hourly wage measure, outliers, defined as individuals whose calculated wage is greater than zero but less than 1.35 (1999 dollars) and two individuals with hourly wages of more than \$250 were eliminated. The results are not affected by the elimination of individuals with very low calculated hourly wages.

\section{Changing levels of lifetime earnings and the skill-premium}

\subsection{Trends in Starting Wages and Wage Growth}

We begin by examining the changes in the wage process, returns to education and returns to experience, that underlie the trend in lifetime earnings inequality. Unlike previous studies that have focused on changes in returns to experience in the cross-section, we analyze changes in actual cohort returns to experience by education group. Since the late 1960s there have been essentially two regimes. The first lasted from approximately the late 1960s through the mid1970s. During this time, college graduates experienced a large decline in starting wages. As can be seen in Table 2, starting hourly wages for college graduates, conditional on positive employment, declined by $\$ 1.10$ in the early 1970 s, while starting wages for other workers changed only a little. The result was that starting wages for these cohorts of workers were 
somewhat compressed relative to the late 1960s. This is not surprising given that returns to education declined throughout this period as the supply of college educated workers increased rapidly (cf. Freeman, 1976). At the same time, wage growth among college graduates increased slightly while wage growth for those with less than a college education declined a bit. The result can be seen in Figure 1, which shows that for low-education workers the wage profiles for the 1975-1978 cohort starts in nearly the same place as the profile for the 1967-1970 cohort, but by the end of ten years, they are earning $\$ 1.25$ to $\$ 1.50$ less. College graduates on the other hand, start off earning $\$ 1.00$ less, but by the end of the period they are earning about $\$ 0.50$ less. So overall, it seems that all workers in the 1975-1978 cohort are worse off than the 1967-1970 cohort, regardless of level of education.

Between the mid-1970s and the late 1980s the story changes. Over this period, starting wages for workers with less than a college education begin to decline more dramatically-with losses ranging from $\$ 0.35$ for drop-outs up to $\$ 1.45$ for high school graduates. ${ }^{14}$ In contrast starting wages for college graduates start to recover from their depressed levels of the mid1970s, gaining back nearly 70 percent of the previous loss. More importantly, wage growth for college graduates spurts during this second period so that cohorts entering the labor market during the late 1980s are actually earning higher wages after ten years than were members of the 1967-1970 cohort (see Figure 1). In contrast, wage growth among low-education workers continues the downward slide begun in the early 1970s so that their wage profiles are everywhere lower than those of the earlier cohorts and by the end of the period they are earning

\footnotetext{
14 These declines in starting wages constitute a significant loss of earnings, even in the first year. The average decline in starting wages between the 1967-1970 cohort and the 1987-1990 cohort was $\$ 0.65$, which would entail a $\$ 1,300$ loss of earnings for someone working 2000 hour a year. A high school graduate entering the labor market in the late 1980s would have earned nearly $\$ 3,400$ less than a comparable worker who started working in 1967-1970, again assuming a 2000 hour year.
} 
about $\$ 2.25$ to $\$ 2.50$. These workers are not making up for lower starting wages with higher wage growth. ${ }^{15}$

More recent cohorts of college graduates not only had higher wage growth than their predecessors, they also increased their wage growth relative to workers with less education. Figure 2 (panel a) shows that among the cohort that entered the labor market between 1967 and 1970, workers with less than a college education experienced wage growth of 60 percent during the first 10 years of their careers, while college graduates experienced about 40 percent wage growth over the same time period. Thus for the early cohort, returns to experience ameliorated the education-based disparities in starting wage. In contrast, hourly wage growth for college graduates who entered the labor market between 1987 and 1990 was over 60 percent, at least as great as that for high school graduates, while the wage growth of high school drop-outs had fallen to 30 percent (panel b). Thus by the late 1980s, returns to experience were exacerbating between-education-group disparities in starting wage. ${ }^{16,17}$

\subsection{Trends in Lifetime Earnings and Lifetime Skill-Premia}

\footnotetext{
${ }^{15}$ One possibility is that men in these cohorts work longer to make up for the lost earnings. We do not explore the issue of retirement age here. However, recent research by Welch and Peracchi (1994) finds that the retirement age has been falling, particularly for low wage workers, suggesting that recent cohorts will not make up the lost earnings through longer careers.

${ }^{16}$ Bernhardt et al., find an increased dispersion in the wage profiles of young men in the NLSY (who entered the labor market in the late 1970s and early 1980s) as compared to those in the NLS-YM (who started working in the mid to late 1960s). However, they do not look at how wage growth has changed across education groups.

${ }^{17}$ The evidence presented here indicates that on average since the late $1960 \mathrm{~s}$, earnings have declined for male workers in the first ten years of their careers. This seems to be at odds with the fact that national income per capita rose over this time period. However, as is discussed in Ellwood (2000), the increase in national income has not been distributed equally. Most of the growth has been in 1) non-earnings sources of income, including profits, interest, rents, and proprietor's income; 2) the earnings of women, who as a group increased their labor force participation substantially over this period; and 3) the earnings of men in the top-third of the income distribution. Other men received less than 15 percent of the increase. Since we focus on young men, only a small proportion of whom are in the top-third of the income distribution, our findings are consistent with the aggregate data.
} 
We now turn to see how these changes in wage growth and starting wages manifested themselves in changes in lifetime earnings. Table 3 displays the undiscounted accumulation of average earnings over the first ten years of the career, including individuals with no earnings in a given year. ${ }^{18}$ On average, cohorts entering the labor market between 1967 and 1970 earned $\$ 267,000$ over the first ten years of their career. In contrast, those entering the labor market between 1987 and 1990 earned $\$ 239,040$-a loss of nearly \$28,000-worth more than a year of work time. This is an important finding. If recent cohorts of workers had lower starting wages but knew that they would be able to make up for it through higher wage growth or more hours of work then consumption would be unchanged (in the case of perfect credit markets) or deferred (if credit markets are imperfect). ${ }^{19}$ Instead, what we find is a reduction in resources for most young men.

Of course, this masks variation both across time periods and across education groups. These more detailed changes are in line with the patterns of starting wages and wage growth described above. Comparing the 1975-1978 cohorts to the 1967-1970 cohorts, we see that declines in earnings did not vary that much by level of education. Losses ranged from $\$ 24,000$ to $\$ 27,000$ over ten years--the exception being the relatively small group of workers with some college education, who lost only $\$ 13,000$. In contrast, comparing the 1987-1990 cohorts to the 1975-1978 cohorts we see that workers with less than a college education experienced additional

\footnotetext{
18 By looking at earnings as opposed to wages and by including individuals with no earnings, we compound the changes in starting wages and wage growth discussed in the previous section with changes in labor force participation and hours of work. However, as we will show in section 6, changes in wages are the most important explanation for changes in lifetime earnings.

19 Of course if young men have to make up for lower wages with more hours of work or if consumption is deferred, then even if total resources are the same, welfare would be reduced under common assumptions about utility functions and discount rates.
} 
losses of between $\$ 20,000$ and $\$ 30,000 .{ }^{20}$ Meanwhile college graduates faced brighter prospects. The 1987-1990 cohort of college graduates had nearly the same lifetime earnings as those in the 1967-1990 cohort. This rebound was due to the recovery of starting wages for these cohorts as well as higher wage growth discussed above, and as we shall see later, a small increase in hours of work.

The increase in lifetime earnings inequality suggested by these numbers is clearly evident in the lifetime skill-premium: the ratio of ten-year earnings for high-skill workers relative to low-skill workers. College graduates entering the labor market in the late 1960s earned 2.6 times as much as their high school dropout counterparts and 1.6 times as much as the high school graduates. For the 1975-1978 cohort, the skill-premium was relatively unchanged, as all groups experienced a comparable decline in earnings. However, as we have seen, during the late 1970s and 1980s this changed and college graduates entering the labor market in the late 1980s earned 3.6 times as much as high school drop-outs and 2.1 times as much as high school graduates over the first ten years. There were also smaller increases in the ratio of the earnings of college graduates to those with some college education and the ratio of those with some college education to high school drop-outs and high school graduates.

To get a sense of the magnitude of these changes, we can compare them to trends in the more commonly discussed cross-sectional earnings premiums. By the late 1980s the crosssectional college/high-school-drop-out skill premium for those with one to ten years of experience had risen about 13 percent from the late 1960s level, while the ten-year wage

\footnotetext{
${ }^{20}$ Cumulatively the losses for workers with a high school degree or less were substantial. The cohort of high school drop-outs that started working in 1987-1990 earned \$44,000 less than the drop-outs who started working in 19671970-a loss of a third of their earnings (using the earlier period as the base). The last cohort of high school graduates lost even more relative to the first cohort in absolute terms: $\$ 59,000$, about 25 percent of the earnings of the earlier cohorts.
} 
premium rose 38 percent over this same time period. Similarly, the college/high school graduate cross-sectional skill premium rose 17 percent between the late 1960s and late 1980s, while the lifetime skill premium rose 31 percent. Interestingly, the cross-sectional wage premium actually declined between the late 1960s and mid-1970s, whereas the ten-year skill-premium was constant for cohorts entering the labor market during these years. This reinforces the argument made here that examining the structure of annual earnings is not sufficient to understand the experience of actual cohorts.

\section{Trends in The Variance of Lifetime Earnings}

\subsection{Measuring Lifetime Earnings Inequality}

We now turn to examine a broader measure of earnings inequality, which will give us a deeper understanding of the recent trends. We focus on the coefficient of variation, which is commonly used in the lifetime earnings inequality literature (Gittleman and Joyce, 1996; Lillard, 1977; Parsons, 1978;). ${ }^{21}$ In order to calculate the coefficient of variation we need a measure of the variance of lifetime earnings. Because we observe at most two years of data for a given individual we cannot calculate the variance of lifetime earnings directly from individual observations, but rather must rely on a model of earnings. Assume that earnings in a given year, $y$, can be described by a Mincer-type wage equation. Then lifetime earnings $(Y)$ is just the sum

21 Another measure of inequality, which is often used to analyze the dispersion of cross-sectional inequality only rarely lifetime inequality, is the variance of log earnings. The variance of log earnings has the advantage that it is invariant to the mean of the data. However, it is difficult to handle individuals who have no earnings in a given year. With panel data, one might think about including only individuals with positive earnings in every year. However, this would ignore an important factor contributing to rising inequality: the increase in the proportion of young men without any earnings in a given year. Even if we wanted to so restrict our analysis, we cannot select such a sample with our data since we only observe individuals over two year. We could assign individuals with no earnings the value of zero or alternately the log of some arbitrarily small number; however, the results are quite sensitive to the imputation method. 
of earnings over the work-life or:

$$
Y_{i s c}=\sum_{T} y_{i s c t}=\sum_{T} \beta_{s c}+r_{s c} \operatorname{Exp}_{s c t}+\varepsilon_{i s c t}
$$

where $i$ indexes individuals, $s$ is the schooling group, $c$ is cohort, and $t$ is the number of years since leaving school. We measure work experience $\left(\operatorname{Exp}_{s c}\right)$ at the cohort/education group level as the sum from the first year in post-schooling until $t$ of the average annual hours worked by the cohort normalized by 2000 hours. In this equation, post-schooling earnings, $\beta_{s c}$, varies by education group and cohort as does the return to experience, $r_{s c}$. The error term $\mathcal{E}_{\text {isct }}$ may be correlated over time. Thus while the variable does not capture actual individual experience it does take into consideration the fact that on average the amount of experience accumulated varies by cohort. For simplicity of exposition we constrain experience to enter linearly, although we will relax this assumption in the estimation.

Given this assumption about the earnings process, the variance of lifetime earnings can be rewritten:

$$
\begin{gathered}
\operatorname{Var}\left(Y_{i s c}\right)=\sum_{t}^{T} \sigma_{\beta_{c}}^{2}+\sigma_{r_{c}}^{2} \operatorname{Exp}_{s c t}^{2}+2 \sigma_{\beta_{c}} \operatorname{Exp}_{s c t}+\sigma_{\varepsilon_{c t}}^{2} \\
+2 \sum_{j} \sum_{k} \sigma_{\beta_{c}}^{2}+\sigma_{r_{c}}^{2}\left(\operatorname{Exp}_{s c j} \operatorname{Exp}_{s c k}\right)+2 \sigma_{\beta_{r c}}\left(\operatorname{Exp}_{s c j}+\operatorname{Exp}_{s c k}\right)+\sigma_{\varepsilon_{j} \varepsilon_{k}} \quad \text { for } \quad k>j
\end{gathered}
$$

where $k$ and $j$ index years since leaving school, $\sigma_{\beta_{c}}^{2}$ measures the variance of the post-schooling earnings for cohort $c, \sigma_{r_{c}}^{2}$ captures cohort $c$ 's variance of returns to experience, and $\sigma_{\beta r_{c}}$ the covariance between them. The between-education-group component, is equal to 


$$
\begin{gathered}
\operatorname{Var}\left(Y_{i s c}\right)=\sum_{t}^{T} \sigma_{\beta_{c}}^{2}+\sigma_{r_{c}}^{2} \operatorname{Exp}_{s c t}^{2}+2 \sigma_{\beta_{r c}} \operatorname{Exp}_{s c t} \\
+2 \sum_{j} \sum_{k} \sigma_{\beta_{c}}^{2}+\sigma_{r_{c}}^{2}\left(\operatorname{Exp}_{s c j} \operatorname{Exp}_{s c k}\right)+2 \sigma_{\beta_{r}}\left(\operatorname{Exp}_{s c j}+\operatorname{Exp}_{s c k}\right) \quad \text { for } \quad k>j .
\end{gathered}
$$

Thus changes in the between-education-group variance component will capture changes in earnings process across education groups such as the changes in starting wages and wage growth discussed previously. ${ }^{22}$

Because we would have only a few observations with which to estimate the parameters determining the between-education-group variance in equation 2, we do not estimate them directly. Instead, we start by estimating the cohort earnings equations in equation one by OLS, using matched CPS data and allowing experience to enter quadratically. We then estimate the between-education-group and within-education-group variance separately. For the betweeneducation-group component we use the coefficients from the earnings regression to calculate predicated cohort-education group lifetime earnings as the sum of predicted earnings over the ten years we observe the cohort $\left(\hat{Y}_{s c}\right)$. Predicted cohort lifetime earnings are calculated in the same way. The between-group variance is then calculated using the standard formula:

$$
\sigma_{b c}^{2}=\sum_{s} p_{s c}\left(\hat{Y}_{s c}-\hat{Y}_{c}\right)^{2}
$$

\footnotetext{
22 The model here does not map perfectly into the discussion in section 4 since here we model earnings and there we discuss wages. As we will show later, however, the changes in inequality appear to be primarily due to changes in wages.
} 
where $p_{s c}$ is the proportion of individuals in education group $s$ in cohort $c .^{23}$

The within-education-group variance is calculated from the residuals of the cohort wage regressions. From equation 3 the within-education-group component of the variance of lifetime earnings is

$$
\sigma_{s c}^{2}=\sum_{t}^{T} \sigma_{\varepsilon_{c}}^{2}+2 \sum_{j}^{T} \sum_{k}^{T} \sigma_{\varepsilon_{j} \varepsilon_{k}} \quad \text { for } \quad k>j
$$

The first term is simply the sum of the within education group variance of earnings for each year and can be easily calculated from our synthetic cohorts. The second term consists of the covariances of individual deviations from the group earnings across years. Using the matched CPS data, in which we observe individuals for two years, we can calculate the first order covariances of the error term. The higher-order covariances can also be calculated if we are willing to make some assumptions about the earning process. Our assumption is that the idiosyncratic component of earnings follows an AR(1) process:

$$
\varepsilon_{i s c t}=\alpha_{s c t}+\rho_{s c t} \varepsilon_{i s c t-1}+\mu_{i s c t}
$$

In this model, the coefficient $\rho_{\text {sct }}$ is the proportional change in the individual component of real earnings and $\mu_{i s c t}$ is mean zero i.i.d shock. Note that $\rho_{c t}$ is not the correlation coefficient unless the variance of $\varepsilon_{i c t}$ is equal to the variance of $\varepsilon_{i c t-1}$, which is generally not the case. Nonetheless, $\rho_{c t}$ still provides information about mobility, with values close to zero implying high mobility. In the limit, if $\rho_{s c t}=0$, then deviations of earnings from the cohort path would consist only of white

\footnotetext{
${ }^{23}$ Note that the between-education group variance is not sensitive to the order of the experience terms included in the wage equation. This is because by construction the predicted lifetime earnings is almost the same as the mean lifetime earning calculated using the method in section 4. An alternative way to calculate the between education group variance is $\sigma_{b c}^{2}=\sum_{s} p_{s c}\left(\bar{Y}_{s c}-\bar{Y}_{c}\right)^{2}$, where $\bar{Y}_{c}$ and $\bar{Y}_{s c}$ are lifetime earnings as calculated in section 4; using this gives nearly the same result.
} 
noise. In contrast, a value of $\rho_{\text {sct }}$ close to 1 implies very low mobility, with $\rho_{s c t}=1$, yielding a random walk. ${ }^{24}$

Based on this model the covariance between $\mathcal{E}_{\text {isct }}$ and $\mathcal{\varepsilon}_{\text {isct- }}$ is simply

$$
\operatorname{Cov}\left(\varepsilon_{i s c t}, \varepsilon_{i s c t-1}\right)=\rho_{s c t} \sigma_{\varepsilon_{s c t-1}}^{2}
$$

It is also possible to calculate higher order covariances, by substitution. The general formula is

$$
\operatorname{Cov}\left(\varepsilon_{i s c t}, \varepsilon_{i s c t-j}\right)=\left(\prod_{k=t-j}^{t-1} \rho_{s c k}\right) \sigma_{s c t-j}^{2} .
$$

Thus, using this model of the earnings process we are able to calculate the covariances necessary to estimate our measure of the within-education-group variance of earnings. To obtain the the $\rho_{c t}$ parameters we estimate equation 6 by OLS using the residuals from the wage regressions. The equation is estimated separately for each education group and cohort. The within variance is then calculated for each cohort/education group using equation 5 and the total within-educationgroup variance for a given cohort is calculated as the weighted sum of the within variance for each education group:

$$
\sigma_{w c}^{2}=\sum_{s} p_{s c} \sigma_{s c}^{2}
$$

Although the model of the error structure is quite simple it accurately captures several relevant features of the data. First, within cohorts the covariance of earnings of a given order increase as the men age, a pattern which has been noted in past studies of mobility (Moffitt and Gottschalk, 1993; Parsons, 1978). This reflects the fact that as they age, workers experience

\footnotetext{
${ }^{24}$ A discussion of the changes in mobility implied by the covariances is beyond the scope of this study, but one which has been undertaken previously, as noted in section 2 .
} 
lower wage growth and more employment stability, both of which decrease mobility. Second, covariances decrease as their order increases, reflecting the fact that the impact of early earnings on future earnings fades out over time. ${ }^{25}$

The model does have some limitations. In particular, it tends to underestimate autocovariances with order 2 or greater (Atkinson et. al, 1992). Past research has indicated that the error structure of earnings is best captured by a permanent component consisting of a random walk or random coefficients model along with a transitory component following a low-order ARMA process (Abowd and Card, 1989; MaCurdy, 1982; Moffitt and Gottschalk, 1993; Haider, 2001). Such a specification can not be identified with the short panels available in the matched CPS. Because we tend to underestimate higher order covariances, our overall measure of lifetime inequality will be too low. This is not a problem in and of itself, since we are primarily interested in the trend. If, however, the fit of the model changes over time, then our results could be affected. Moffitt and Gottschalk (1993) find that the autocovariances of wage and salary income do fade out more slowly in the 1980s than in the 1970s (see also Gittleman and Joyce, 1996 on this point), a fact observed in our estimates of the covariances as well. Nonetheless, to the extent that we underestimate the higher order covariances more severely in the 1980s than we do in the 1970s, the result is that we also underestimate the variance of lifetime earnings more in later years. This means any increase in within-education-group lifetime earnings inequality and hence total inequality that we find should be considered a lower bound estimate.

5.2 Trends in lifetime earnings inequality

${ }^{25}$ The variance-covariance matrices for each cohort are available from the author upon request. 
Table 4 presents the coefficient of variation of ten-year earnings calculated using the variances estimated in the previous section. The data show a clear increase in long-term earnings inequality since the late 1960 s. The coefficient of variation rose from 0.37 for cohorts entering the labor market in the late 1960 s to 0.51 for those starting to work in the mid-1980s and then remained constant at this higher level for those who began working later in the decade. ${ }^{26}$ Table 5 shows a decomposition of the change in the variance of lifetime earnings into the change in between-education-group inequality and the change in within-education-group inequality. Looking at the decomposition of changes in lifetime earnings inequality from the first to last cohort we see that the rise in within-group inequality explains 65 percent of the increase in inequality while the increase in between-group inequality explains the rest. The contribution of changes in educational composition (to both the within- and between-group inequality) is 8 percent. However, the table also makes clear that the changes in inequality among the cohorts had different underlying causes than the changes among the later cohorts. The growth in inequality between the $1967-1970$ cohort and the $1975-1978$ cohort is more than accounted for by the increase in within-education-group inequality during that period. Betweengroup inequality actually declined during this period. This finding is not surprising given the evidence presented in section 4 , where we showed that over this period starting wages for college graduates fell significantly while their returns to experience had increased only slightly. Correspondingly the skill premium was also fairly flat during this period. In contrast, the rise in between-education-group inequality accounts for 54 percent of the total increase in inequality between the 1975-1978 cohort and the 1987-1989 cohort, supporting the evidence presented

\footnotetext{
26 The results presented here differ from those presented in Haider (2001). He finds that lifetime earnings inequality remains fairly flat during the 1970 s and rises only in the 1980 s. This discrepancy in results may be due to the fact that he identifies lifetime earnings inequality largely from changes in the cross-sectional wage profile.
} 
previously that factors such as the changes in returns to experience did play an important role in increasing inequality during this later period.

There are significant differences in both the levels and trends in inequality across education groups. As can be seen in Table 4, within-education-group inequality is highest for high school drop-outs, who have an average coefficient of variation of approximately 0.57 , and then declines monotonically with level of education to an average of 0.33 for workers with a college degree or more. All education groups experienced an increase in within group inequality between the late 1960s and late 1980s. The increase in inequality was highest for those with a high school degree (46 percent) and was a bit lower for those with some college or more. ${ }^{27}$ Among high school drop-outs inequality increased through the early 1980s and then declined, remaining 21 percent higher at the end of the period than it had been at the beginning. Some of the increase in within-group inequality among the more educated groups may be attributable to changes in the attributes of workers within education groups as educational attainment increased over the time period. ${ }^{28}$

As a point of comparison, Table 6 presents data on the coefficient of variation of for individuals with one to ten years of potential experience in a cross-section. The cross-sectional coefficient of variation is larger than the coefficient of variation of ten-year earnings, which accords with the notion that transitory differences in earnings between individuals average out over time. However, the coefficient of variation of ten-year earnings increased by more than the

\footnotetext{
27 The finding of comparatively small increase in inequality among college graduates may be a function of the elimination of individuals with top coded data.

28 For instance, in a simple Roy-type model (Roy, 1951) in which individuals choose to work in one of two sectors characterized by the level of education (high or low) required to perform the job, a change in relative prices that induces individuals to shift from the low education to the high education sector increases the variance of wages in the high-education sector and reduces the variance of wages in the low-education sector.
} 
increase in the cross-sectional coefficient of variation both for the sample as a whole and within education groups. This provides support for the hypothesis proposed by Juhn et al., (1993) that the observed increases in annual within-education group earnings inequality are due, at least in part, to persistent factors, such as increased returns to unobserved ability, rather than increases in the transitory components of earnings.

To summarize, the data provide a clear indication that long-term earnings inequality was higher for those entering the labor market during the 1980s than for those who entered the labor market in the late 1960s. Across the entire time period, the increase in within-group inequality, explains somewhat more of the increase in inequality. However, between-education-group inequality explains a larger proportion of the increase in lifetime earnings inequality between cohorts entering the labor market in 1975-1978 and those entering in 1987-1990, indicating that the change in the distribution of returns to experience across education groups has contributed to an increase in lifetime inequality.

\section{The role of wages and work}

6.1 The levels of wages and hours

Earnings are a function of both wages and hours worked. As we saw in section 4, over the past 30 years there has been a decline in starting wages for those who work. Over the same time period there has also been a large increase in the proportion of men who don't work at all in a given year and a decrease in annual hours worked conditional on positive employment (cf. Juhn, 1992; Juhn et al., 1991; Welch, 1997). Only the most recent cohorts of college graduates are working more than their predecessors, largely as a result of an increase in usual hours worked per week. Although it seems likely that both changes in wages and changes in hours 
worked have contributed to the decline in lifetime earnings, further analysis is required to determine their relative importance. ${ }^{29}$

To start we decompose changes in earnings into changes in wages and changes in hours of work. If we write annual wage and salary income as the product of the hourly wage and total hours worked, then the average annual lifetime earnings, $Y_{c}$, for members of cohort $c$ can be written as

$$
Y_{c}=\sum_{i=1}^{T} y_{c t}=\sum_{t=1}^{T} \overline{w_{i c t} \text { tothrs }_{i c t}}
$$

where $y_{c t}$ is the average annual wage and salary income for members of cohort $c$ in the $t^{\text {th }}$ year of labor market experience, $w_{i c t}$ is the average wage of individual $i$ in cohort $c$ at time $t$ and tothrs $s_{i c t}$ is the total hours worked by that individual, as described above. The bar over the variable $\overline{w_{\text {ict }} \text { tothrs }_{\text {ict }}}$ is simply a reminder that lifetime earnings is calculated as the sum of the mean earnings in each year. By adding and subtracting $\overline{w_{i l t}} \overline{t o t h r s_{j c t}}$, we can see that the difference in lifetime earnings between the first cohort and cohort $c$ can be decomposed as follows:

$$
\begin{gathered}
Y_{1}-Y_{c}=\sum_{t=1}^{T} y_{1 t}-y_{c t}= \\
\sum_{t=1}^{T}\left(\overline{w_{i l t} \text { tothrs }_{i l t}}-\overline{w_{i t t}} \overline{\text { tothrs }_{j c t}}\right)+\left(\overline{w_{i l t}} \text { tothrs }_{j c t}-\overline{w_{j c t} \text { tothrs }_{j c t}}\right)
\end{gathered}
$$

with $\overline{w_{i c t}}$ equal to the average hourly wage for cohort $c$ in year $t$ and $\overline{\text { tothrs }_{\text {ict }}}$ equal to the average

\footnotetext{
${ }^{29}$ In this analysis, we treat changes in labor force participation and the choice of annual hours conditional on participation as exogenous and do not take into account the fact that changes in employment may themselves be the result of changes in wages and vice versa.
} 
hours of work. ${ }^{30}$ The first term of the second line represents the loss of income due to the change in the hours worked, holding wages fixed at the average level of the first cohort. The second term represents the loss of income due to the change in wages between the two cohorts, holding total hours constant at the current average level. However, this decomposition is not unique. It would also be possible to add and subtract $\overline{w_{\text {jct }} \text { tothrs }}$, in which case the weight on the change in hours would be the current cohort wage and the weight on the change in wages would be the initial cohort hours. Because there is no obvious reason to prefer one decomposition to the other, we present the average of the two.

Table 7 presents results from the decomposition. For the sample as a whole, the decline in hourly wages is the largest factor contributing to the decline in lifetime earnings relative to the 1967-1970s cohort. However, the decline in hours worked is an important factor for the cohorts that started working in the 1970s, explaining over 40 percent of the fall in lifetime earnings for the 1971-1974 cohorts. In absolute terms, the loss of earnings due to low total hours was the largest for cohorts entering the labor market between 1975 and 1978. These workers would have earned an additional $\$ 5,380$, if they had worked the same total hours as the earliest cohorts.

For low-skill young men, the decline in total hours worked was a particularly important factor in explaining the decline in lifetime earnings. Among high school drop-outs and high school graduates the average loss of earnings due to decreased participation and annual hours of work reached as high as $\$ 16,620$ and $\$ 9,170$ respectively. Furthermore, the change in total hours constitutes a large proportion of the total decline in earnings for those entering the labor

30 It is the case that for two random variables, $\mathrm{X}$ and $\mathrm{Y}, E(X) E(Y)=E(X Y)-\operatorname{cov}(X, Y)$. However, because the covariance between the wages in of individuals in the first cohort and the hours of work among individuals in the a later cohort is zero our estimate of $E\left(w_{i l t} t_{t o t h r} s_{j c}\right)$ is unbiased. 
market in the 1970s. For the 1971 to 1974 cohort, the change in annual hours more than explains the decline in lifetime earnings among high school drop-outs and accounts for 72 percent of the decline among high school graduates relative to the 1967-1970 cohort. Over time, this proportion declines, but it remains higher than the average for all workers.

For the more highly skilled, the pattern is somewhat different. Young men with at least some college education or a college degree who entered the labor force in the 1970s did not see a large decline in total hours relative to the 1967-1970 cohort and their losses in earnings due to changes in total hours were small both in absolute and percentage terms. In fact, cohorts that started working in the mid-1970s increased their hours of work relative to the first cohort. For those with some college education the change in labor supply did not have a significant impact on their lifetime earnings, but later cohorts of college graduates were able to offset their relatively small wage losses by working more.

\subsection{The variance of lifetime wages and hours}

Another way to examine the contribution of changes in the distribution of wages and work to trends in lifetime inequality is to examine their variances. Changes in lifetime earnings can be decomposed into a function of the variances and covariances of hourly wages earned in each year and the variances and covariances of hours of work, although these components are not exhaustive. ${ }^{31}$ We summarize these data by presenting the coefficient of variation of hourly wages and hours of work in tables 8 and 9 . In order to avoid calculating the covariances using

\footnotetext{
${ }^{31}$ One interesting question is whether we expect the earnings inequality to change by more or less than the underlying change in wage inequality. As long as the change in the variance of hours of work is positive then earnings inequality will grow by more than wage inequality. Moreover, there is some evidence that the increase in cross-sectional wage inequality has resulted in an increase in the variance of hours worked in the cross-section (Welch, 1997).
} 
imputed data, this portion of the analysis is only implemented for the 4 cohorts entering the labor market since $1976 .{ }^{32}$ The coefficients of variation of hourly wages for the sample as a whole is about 75 percent larger than that for total hours. Within education groups, the inequality of wages and total hours is comparable for high school drop-outs, while for other groups of workers, wage inequality is up to twice as large as the inequality in hours worked.

The level of inequality in ten-year hourly wages across education groups is higher for those with low education, although the differences are comparatively small. The coefficient of variation of total hours is also higher for workers with less education, but in this case the differences are substantial: inequality of total hours among high school drop-outs is at least twice as high as for young men with at least some college education.

From these data it appears that the increase in lifetime earnings inequality is due primarily to a rise in the variance of hourly wages. The coefficient of variation of hourly wages increased by 10 percent from the mid-1970s to the mid-1980s. Moreover, this path corresponds with that of the coefficient of variation of annual earnings.

There has been no trend in overall inequality of total hours either for the sample as a whole or within education groups. Annual hours does exhibit some evidence of cyclical behavior. It is highest for the cohorts entering the labor market during the back-to-back recessions of 1980 and 1981, despite the fact that for most of the ten years for which we observe these individuals they experienced relatively strong labor markets. Within-education-groups the pattern is essentially the same, with the 1979-1982 cohort exhibiting a higher variance of total hours.

32 See section 3 for a discussion of the hours and weeks worked data. 
Taking into account both of the analyses presented in this section, it seems clear that observed increases in lifetime inequality are largely due to changes in the distribution of hourly wages. That said, changes in the number of hours worked does appear to have contributed to the increase in between-education-group inequality of lifetime earnings.

\section{Conclusions}

In this paper, we document a decrease in lifetime earnings for low-skill workers and a significant increase in lifetime earnings inequality. The increase is even larger than the much more widely reported increase in cross-sectional earnings inequality. By examining the issue of inequality from a lifecycle perspective, we gain a new understanding of how changes in the returns to skill and experience affect earnings. During the 1970s, a decade which saw a decline in returns to education, the increase in lifetime inequality was largely due to an increase in the variance of earnings within education groups. In contrast, the between-education variance of earnings became a more important factor during the 1980s when both returns to education and returns to experience changed in ways that favored high-skill young men. We also find that while most of the increase in inequality during the late 1970s and early 1980s resulted from an increase in the dispersion of hourly wages, declines in the hours of work among low-skill young workers significantly lowered their lifetime earnings in the early 1970s and contributed to an increase in between-group earnings inequality.

This suggests future areas of research as there has been little work exploring how cohort/education group wage growth has changed over time and in particular what forces may lie behind the apparent increase in the correlation between education and returns to experience (cf. 
Aaronson, 2001; Mroz and MaCurdy, 1995). Understanding the forces underlying these changes will provide us with further insight into labor market developments over the past 30 years.

The decrease in lifetime earnings documented here also has important implications for trends in socio-economic outcomes. For instance the large decline in earnings over the first ten years of the career could partly explain the low rates of home ownership (Cameron and Tracy, 1997) and the decline in marriage rates (Wilson, 1987; Wood, 1995; Blau et al., 2000) among recent cohorts of young men. 


\section{References}

Aaronson, Stephanie. "Technology, demography, and wage growth." Board of Governors of the Federal Reserve System, November, 2001.

Abowd, John M., and David Card. "On the covariance structure of earnings and hours changes." Econometrica 57 (March 1989): 411-445.

Atkinson, A.B., F. Bourguinon, and C. Morrisson. Empirical Studies of Earnings Mobility. Fundamentals of Pure and Applied Economics, vol. 52. Chur, Switzerland, Harwood Academic Publishers, 1992.

Bernhardt, Annette, Martina Morris, and Mark Handcock. Inequality and mobility: trends in wage growth for young adults. Population Research Institute. 99-03. Pennsylvania State University, 1998. 40.

Bishop, John A., Jong-Rong Chiou, and John P. Formby. "Truncation bias and the ordinal evaluation of income inequality." Journal of Business and Economic Statistics 12 (January 1994): 123-127.

Blau, Francine D., Lawrence M. Kahn, and Jane Waldfogel. "Understanding young women's marriage decisions: the role of labor and marriage market conditions." Industrial and Labor Relations Review 53 (July 2000): 624-647.

Borjas, George J, , Richard B. Freeman, and Lawrence F. Katz. "How much do immigration and trade affect labor market." Brookings Papers on Economic Activity 1997, no. 1 (1997): $1-67$.

Buchinsky, Moshe, and Jennifer Hunt. "Wage mobility in the United States." Review of Economics and Statistics 81 (August 1999): 351-368.

Cameron, Stephen, and Joseph Tracy. "The transition to homeownership; the importance of early career concerns," April, 1997.

Creedy, John. "Lifetime versus annual income distribution." In Handbook of income inequality measurement, edited by Jacques Silber, 513-33. Recent Economic Thought, vol. 71. Boston, Kluwer Academic, 1999.

Ellwood, David T. "Winners and losers in America: taking the measure of the new economic realities," edited by David T. Ellwood, 1-41. New York, Russell Sage Foundation, 2000.

Fichtenbaum, Rudy, and Hushang Shahidi. "Truncation bias and the measurement of income inequality." Journal of Business and Economic Statistics 6 (July 1988): 335-337. 
Freeman, Richard B. The overeducated American. New York, Academic Press, 1976.

Gittleman, Maury, and Mary Joyce. "Earnings mobility in the United States, 1967-1991." Monthly Labor Review, September 1995, 3-13.

------, and Mary Joyce. "Earnings mobility and long-run inequality: An analysis using matched CPS data." Industrial Relations 35 (April 1996): 180-196.

Gottschalk, Peter, and Robert A. Moffitt. Earnings and wage distributions. National Bureau of Economic Research. Final report to the U.S. Department of Labor, Grant No. E-9-J-0047, 62 pages, 1992.

------, and Robert A. Moffitt. "The growth of earnings instability in the U.S. labor market." Brookings Papers on Economic Activity, no. 2 (1994): 217-272.

Haider, Steven. "Earnings instability and earnings inequality of males in the United States: 1967-1991." Journal of Labor Economics 19, no. 4 (2001): 799-836.

Hungerford, Thomas L. "U.S. income mobility in the seventies and eighties." Review of Income and Wealth 39 (December 1993): 403-417.

Juhn, Chinhui, Kevin M. Murphy, and Brooks Pierce. "Wage inequality and the rise in returns to skill." Journal of Political Economy 101, no. 3 (1993): 410-442.

------, Kevin M. Murphy, and Robert H. Topel. "Why has the natural rate of unemployment increased over time." Brookings Papers on Economic Activity 2 (1991): 75-141.

Levy, Frank, and Richard Murnane. "U.S. Earnings Levels and Earnings Inequality: A Review of Recent Trends and Proposed Explanations." Journal of Economic Literature XXX (September 1992): 1333-1381.

Lillard, Lee A. "Inequality: earnings vs. human wealth." American Economic Review 67 (March 1977): $42-53$.

------, James P. Smith, and Finis Welch. "What do we really know about wages? The importance of nonreporting and census imputation." Journal of Political Economy 94 (June 1986): 489-506.

MaCurdy, Thomas, E. "The use of time series processes to model the error structure of earnings in a longitudinal data analysis." Journal of Econometrics 18 (1982): 83-114.

MaCurdy, Thomas, and Thomas Mroz. "Measuring macroeconomic shifts in wages from cohort specifications," Revised September, 1995.

Mincer, Jacob. Schooling, Experience, and Earnings. New York, Columbia University Press, 
1974.

Moffitt, Robert A., and Peter Gottschalk. "Trends in the autocovariance structure of earnings in the U.S.: 1969-1987." Revised July 1995, June 1993.

Murphy, Kevin M., and Finis Welch. "Empirical age-earnings profiles." Journal of Labor Economics 8, no. 2 (1990): 202-229.

Parsons, Donald O. "The autocorrelation of earnings, human welath inequality, and income contingent loans." Quarterly Journal of Economics 92 (November 1978): 551-569.

Peracchi, Franco, and Finis Welch. "How representative are matched cross-sections? Evidence from the Current Population Survey." Journal of Econometrics 68 (July 1995): 153-179.

Roy, A.D. "Some thoughts on the distribution of earnings." Oxford Economic Papers (New Series) 3 (1951): 135-146.

Shorrocks, Anthony. "Income inequality and income mobility." Journal of Economic Theory 19, no. 4 (1978): 376-393.

Welch, Finis. "Wages and participation." Journal of Labor Economics 15, no. 1, pt. 2 (1997): S77-S103.

------, and Franco Peracchi. "Trends in labor force transitions of older men and women." Journal of Labor Economics 12 (April 1994): 210-242.

Wilson, William Julius. The truly disadvantaged. Chicago, University of Chicago Press, 1987.

Wood, Robert G. "Marriage rates and marriageable men: A test of the Wilson hypothesis." Journal of Human Resources 30, no. 1 (1995): 163-193. 
Figure 1

Hourly Wage Profiles for Workers Entering the Labor Market in the Periods 1967-1979, 1975-1978, and 1987-1990

by Level of Education
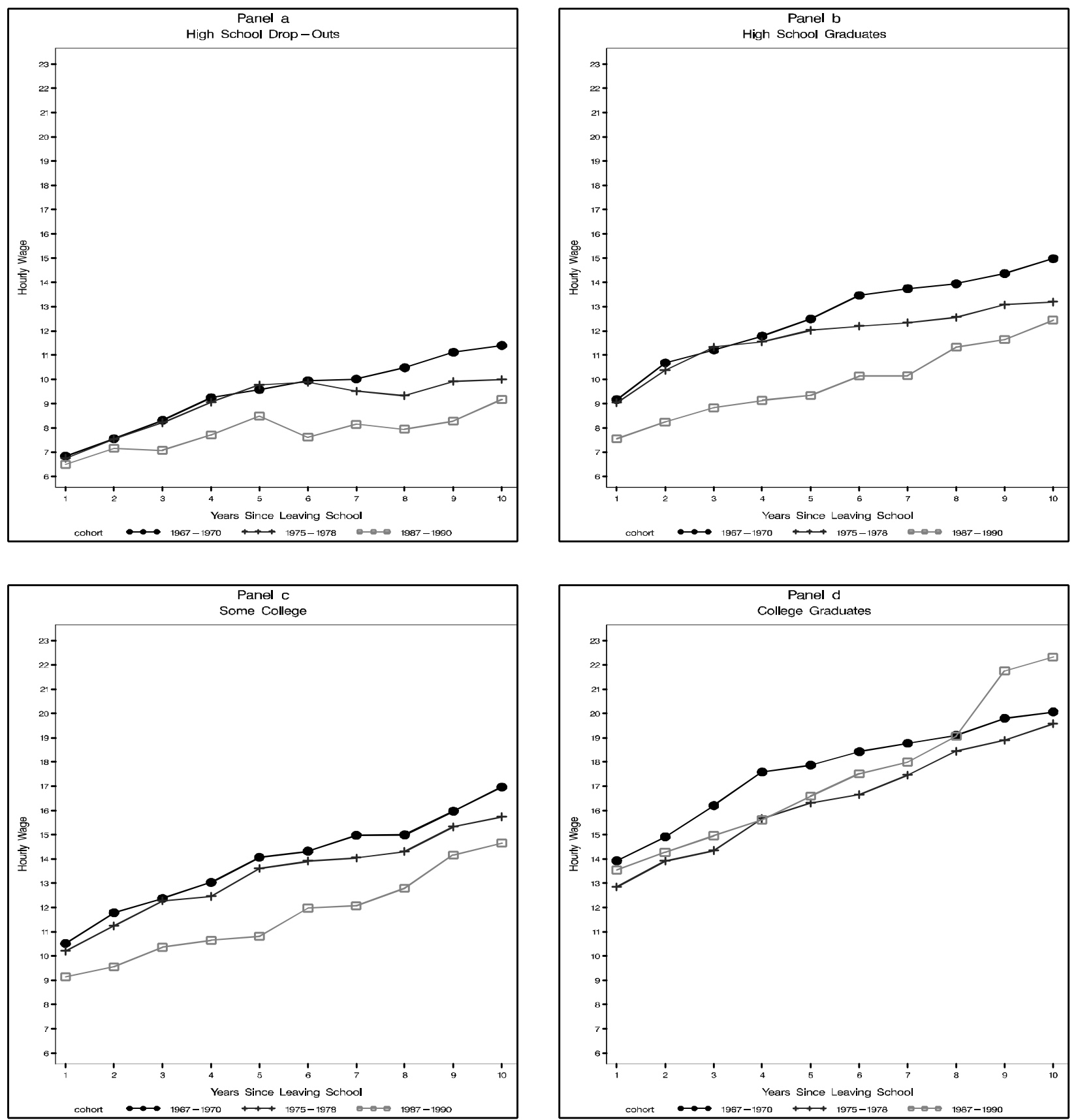

Notes:

1. Data are from the March Demographic Supplement to the Current Population Survey 1968-2000. See Section 3 for sample inclusion criteria and a description of the wage data. Wages are deflated to 1999 dollars using the Personal Consumption Expenditure Deflator. 


\section{Figure 2}

Hourly Wage Profiles for Workers with Different Levels of Education, by Year of Entry into the Labor Market
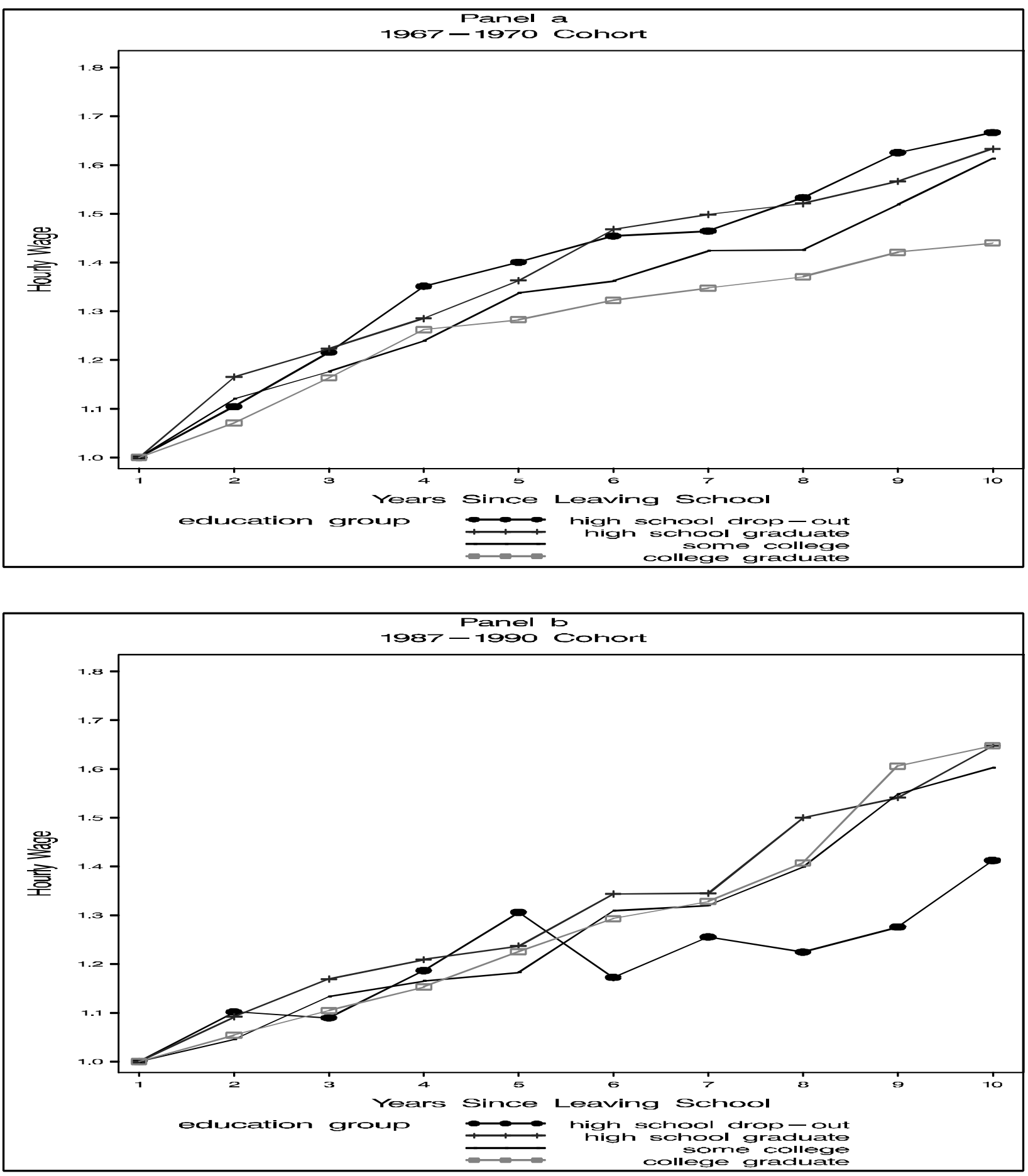

Notes:

1. Data are from the March Demographic Supplement to the Current Population Survey 1968-2000. See Section 3 for sample inclusion criteria and a description of the wage data. Wages are deflated to 1999 dollars using the Personal Consumption Expenditure Deflator. 


\begin{tabular}{|c|c|c|c|}
\hline \multicolumn{4}{|c|}{$\begin{array}{l}\text { Table } 1^{\mathrm{a}} \\
\text { Average sample size for cohort/experience cells } \\
\text { in the unmatched and matched } \mathrm{cps}\end{array}$} \\
\hline Cohort & & $\begin{array}{l}\text { Average Number of Obs. per } \\
\text { Cohort/Experience Cell in Cross- } \\
\text { Section }\end{array}$ & $\begin{array}{c}\text { Average Number of Obs. per } \\
\text { Cohort/Experience Cell in } \\
\text { Matched Data }\end{array}$ \\
\hline \multirow[t]{4}{*}{1} & High school drop-outs & 471 & 64 \\
\hline & High school graduates & 919 & 164 \\
\hline & Some College & 691 & 129 \\
\hline & College Graduates & 631 & 126 \\
\hline \multirow[t]{4}{*}{2} & High school drop-outs & 540 & 102 \\
\hline & High school graduates & 1249 & 297 \\
\hline & Some College & 921 & 217 \\
\hline & College Graduates & 908 & 245 \\
\hline \multirow[t]{4}{*}{3} & High school drop-outs & 587 & 111 \\
\hline & High school graduates & 1467 & 350 \\
\hline & Some College & 898 & 202 \\
\hline & College Graduates & 941 & 247 \\
\hline \multirow[t]{4}{*}{4} & High school drop-outs & 530 & 102 \\
\hline & High school graduates & 1364 & 310 \\
\hline & Some College & 779 & 175 \\
\hline & College Graduates & 891 & 233 \\
\hline \multirow[t]{4}{*}{5} & High school drop-outs & 399 & 74 \\
\hline & High school graduates & 1097 & 254 \\
\hline & Some College & 753 & 166 \\
\hline & College Graduates & 794 & 196 \\
\hline \multirow[t]{4}{*}{6} & High school drop-outs & 350 & 55 \\
\hline & High school graduates & 802 & 177 \\
\hline & Some College & 655 & 137 \\
\hline & College Graduates & 707 & 163 \\
\hline
\end{tabular}

${ }^{\mathrm{a}}$ Notes:

1. Data are from the March Demographic Supplement to the Current Population Survey 1968-2000. See Section 3 for sample inclusion criteria and a description of the data.

2. The matched data are two-year panels in which individuals are linked across adjacent years of the March CPS. See Section 3 for a further description of the data. 


\begin{tabular}{|c|c|c|c|c|c|c|c|c|c|c|c|c|c|}
\hline \multicolumn{14}{|c|}{$\begin{array}{l}\text { Table } 2^{\mathrm{a}} \\
\text { Starting wages and wages after } 10 \text { years of experience }\end{array}$} \\
\hline \multicolumn{2}{|c|}{$\begin{array}{l}\text { Years of Entry into the } \\
\text { Labor Market }\end{array}$} & \multicolumn{2}{|c|}{$\begin{array}{l}1967- \\
1970\end{array}$} & \multicolumn{2}{|c|}{$\begin{array}{l}1971- \\
1974\end{array}$} & \multicolumn{2}{|c|}{$\begin{array}{l}1975- \\
1978\end{array}$} & \multicolumn{2}{|c|}{$\begin{array}{l}1979- \\
1982\end{array}$} & \multicolumn{2}{|c|}{$\begin{array}{l}1983- \\
1986\end{array}$} & \multicolumn{2}{|c|}{$\begin{array}{l}1987- \\
1990\end{array}$} \\
\hline \multirow[t]{2}{*}{$\begin{array}{l}\text { All } \\
\text { Workers }\end{array}$} & $\begin{array}{l}\text { Starting } \\
\text { Wage }\end{array}$ & $\$$ & 10.14 & $\$$ & 10.36 & $\$$ & 9.98 & $\$$ & 9.84 & $\$$ & 8.99 & $\$$ & 9.49 \\
\hline & $\begin{array}{l}\text { Wage in } \\
10^{\text {th }} \text { Year }\end{array}$ & $\$$ & 16.25 & $\$$ & 15.71 & $\$$ & 15.06 & $\$$ & 14.90 & $\$$ & 14.55 & $\$$ & 15.32 \\
\hline \multirow{2}{*}{$\begin{array}{l}\text { High } \\
\text { School } \\
\text { Drop-Outs }\end{array}$} & $\begin{array}{l}\text { Starting } \\
\text { Wage }\end{array}$ & $\$$ & 7.24 & $\$$ & 7.33 & $\$$ & 7.08 & $\$$ & 7.07 & $\$$ & 6.26 & $\$$ & 6.74 \\
\hline & $\begin{array}{l}\text { Wage in } \\
10^{\text {th }} \text { Year }\end{array}$ & $\$$ & 11.52 & $\$$ & 10.83 & $\$$ & 10.23 & $\$$ & 9.30 & $\$$ & 8.44 & $\$$ & 9.26 \\
\hline \multirow{2}{*}{$\begin{array}{l}\text { High } \\
\text { School } \\
\text { Graduates }\end{array}$} & $\begin{array}{l}\text { Starting } \\
\text { Wage }\end{array}$ & $\$$ & 9.41 & $\$$ & 9.77 & $\$$ & 9.17 & $\$$ & 8.92 & $\$$ & 7.75 & $\$$ & 7.72 \\
\hline & $\begin{array}{l}\text { Wage in } \\
10^{\text {th }} \text { Year }\end{array}$ & $\$$ & 15.03 & $\$$ & 14.77 & $\$$ & 13.25 & $\$$ & 12.76 & $\$$ & 12.30 & $\$$ & 12.51 \\
\hline \multirow[t]{2}{*}{$\begin{array}{l}\text { Some } \\
\text { College }\end{array}$} & $\begin{array}{l}\text { Starting } \\
\text { Wage }\end{array}$ & $\$$ & 10.63 & $\$$ & 10.30 & $\$$ & 10.24 & $\$$ & 10.09 & $\$$ & 9.24 & $\$$ & 9.24 \\
\hline & $\begin{array}{l}\text { Wage in } \\
10^{\text {th }} \text { Year }\end{array}$ & $\$$ & 17.04 & $\$$ & 15.33 & $\$$ & 15.79 & $\$$ & 15.57 & $\$$ & 14.14 & $\$$ & 14.70 \\
\hline \multirow[t]{2}{*}{$\begin{array}{l}\text { College } \\
\text { Graduates }\end{array}$} & $\begin{array}{l}\text { Starting } \\
\text { Wage }\end{array}$ & $\$$ & 13.97 & $\$$ & 13.51 & $\$$ & 12.87 & $\$$ & 13.36 & $\$$ & 12.95 & $\$$ & 13.62 \\
\hline & $\begin{array}{l}\text { Wage in } \\
10^{\text {th }} \text { Year }\end{array}$ & $\$$ & 20.12 & $\$$ & 19.92 & $\$$ & 19.63 & $\$$ & 21.04 & $\$$ & 20.41 & $\$$ & 22.39 \\
\hline
\end{tabular}

a Notes:

1. Data are from the March Demographic Supplement to the Current Population Survey 1968-2000. Individuals with no earnings in the given year are excluded from the analysis. See Section 3 for sample inclusion criteria and a description of the wage data. Wages are deflated to 1999 dollars using the Personal Consumption Expenditure Deflator. 


\begin{tabular}{|l|c|c|c|c|c|c|}
\hline \multicolumn{7}{|c|}{$\begin{array}{c}\text { Table } 3^{\text {a }} \\
\text { Ten-year earnings }\end{array}$} \\
\hline $\begin{array}{l}\text { Years of Entry into } \\
\text { the Labor Market }\end{array}$ & $\begin{array}{c}1967- \\
1970\end{array}$ & $\begin{array}{c}1971- \\
1974\end{array}$ & $\begin{array}{c}1975- \\
1978\end{array}$ & $\begin{array}{c}1979- \\
1982\end{array}$ & $\begin{array}{c}1983- \\
1986\end{array}$ & $\begin{array}{c}1987- \\
1990\end{array}$ \\
\hline All Workers & $\$ 267,000$ & $\$ 257,570$ & $\$ 247,310$ & $\$ 240,860$ & $\$ 238,380$ & $\$ 239,040$ \\
\hline \hline $\begin{array}{l}\text { High School Drop- } \\
\text { Outs }\end{array}$ & $\$ 149,940$ & $\$ 143,260$ & $\$ 125,840$ & $\$ 106,910$ & $\$ 103,340$ & $\$ 105,880$ \\
\hline $\begin{array}{l}\text { High School } \\
\text { Graduates }\end{array}$ & $\$ 244,220$ & $\$ 232,260$ & $\$ 217,080$ & $\$ 201,880$ & $\$ 188,520$ & $\$ 184,920$ \\
\hline Some College & $\$ 273,250$ & $\$ 263,090$ & $\$ 259,570$ & $\$ 253,480$ & $\$ 240,330$ & $\$ 229,900$ \\
\hline College Graduates & $\$ 383,320$ & $\$ 357,050$ & $\$ 357,050$ & $\$ 379,090$ & $\$ 384,380$ & $\$ 386,350$ \\
\hline
\end{tabular}

a'Notes:

1. Data are from the March Demographic Supplement to the Current Population Survey 1968-2000. See Section 3 for sample inclusion criteria and a description of the wage data. Wages are deflated to 1999 dollars using the Personal Consumption Expenditure Deflator.

2. Ten year earnings are the sum of wage and salary earnings over the first ten years of the career. 


\begin{tabular}{|l|r|r|r|r|r|r|}
\hline \multicolumn{7}{|c|}{$\begin{array}{c}\text { Table 4 } \\
\text { Coefficient of variation of ten-year earnings } \\
\text { for men with 1 to 10 years of experience }\end{array}$} \\
\hline $\begin{array}{l}\text { Years of } \\
\text { Entry into } \\
\text { the Labor } \\
\text { Market }\end{array}$ & $1967-1970$ & $1971-1974$ & $1975-1978$ & $1979-1982$ & $1983-1986$ & $1987-1990$ \\
\hline All Workers & 0.40 & 0.43 & 0.47 & 0.54 & 0.54 & 0.53 \\
\hline \hline $\begin{array}{l}\text { High School } \\
\text { Drop-Outs }\end{array}$ & 0.47 & 0.57 & 0.61 & 0.63 & 0.56 & 0.57 \\
\hline $\begin{array}{l}\text { High School } \\
\text { Graduates }\end{array}$ & 0.30 & 0.35 & 0.39 & 0.42 & 0.41 & 0.44 \\
\hline $\begin{array}{l}\text { Some } \\
\text { College }\end{array}$ & 0.28 & 0.32 & 0.35 & 0.39 & 0.39 & 0.39 \\
\hline $\begin{array}{l}\text { College } \\
\text { Graduates }\end{array}$ & 0.28 & 0.31 & 0.33 & 0.36 & 0.35 & 0.37 \\
\hline
\end{tabular}

\section{${ }^{\mathrm{a}}$ Notes:}

1. Data are from the March Demographic Supplement to the Current Population Survey 1968-2000. Individuals with zero earnings are included in the sample. See Section 3 for other sample inclusion criteria and a description of the wage data. Wages are deflated to 1999 dollars using the Personal Consumption Expenditure Deflator. Section 5.

2. For formulas used to calculate the variance of ten-year earnings underlying the coefficient of variation see 


\begin{tabular}{|c|c|c|c|c|c|}
\hline \multicolumn{6}{|c|}{$\begin{array}{l}\text { Table } 5^{\mathrm{a}} \\
\text { Decomposition of the change in the variance of lifetime earnings into } \\
\text { changes in within- and between-education group variances }\end{array}$} \\
\hline \multirow{2}{*}{$\begin{array}{l}\text { Cohorts being } \\
\text { differenced }\end{array}$} & \multirow{2}{*}{$\begin{array}{l}\text { Total change } \\
\text { in variance } \\
\text { (billions) }\end{array}$} & \multicolumn{2}{|c|}{$\begin{array}{l}\text { Proportion of change due to within } \\
\text { variance change }\end{array}$} & \multicolumn{2}{|c|}{$\begin{array}{c}\text { Proportion of change due to } \\
\text { between variance change }\end{array}$} \\
\hline & & $\begin{array}{l}\text { Change in } \\
\text { Composition }\end{array}$ & $\begin{array}{l}\text { Change in } \\
\text { Variance }\end{array}$ & $\begin{array}{l}\text { Change in } \\
\text { Composition }\end{array}$ & $\begin{array}{l}\text { Change in } \\
\text { Variance }\end{array}$ \\
\hline $\begin{array}{l}1967-1970- \\
1987-1990\end{array}$ & 7.99 & 0.07 & 0.58 & 0.01 & 0.34 \\
\hline $\begin{array}{l}1967-1970- \\
1975-1978\end{array}$ & 1.44 & 0.00 & 1.49 & -0.07 & -0.42 \\
\hline $\begin{array}{l}1975-1978- \\
1987-1990\end{array}$ & 6.55 & 0.07 & 0.39 & 0.01 & 0.53 \\
\hline
\end{tabular}

\footnotetext{
Notes:

1. Data are from the March Demographic Supplement to the Current Population Survey 1968-2000. Individuals with zero earnings are included in the sample. See Section 3 for other sample inclusion criteria and a description of the wage data. Wages are deflated to 1999 dollars using the Personal Consumption Expenditure Deflator.
} 


\begin{tabular}{|l|r|r|r|r|r|r|}
\hline \multicolumn{7}{|c|}{$\begin{array}{l}\text { Table 6 }^{\text {a }} \\
\text { Coefficient of variation of cross-sectional earnings } \\
\text { for men with 10 10 years of experience }\end{array}$} \\
\hline Years & $1967-1970$ & $1971-1974$ & $1975-1978$ & $1979-1982$ & $1983-1986$ & $1987-1990$ \\
\hline All Workers & 0.63 & 0.60 & 0.61 & 0.65 & 0.72 & 0.71 \\
\hline \hline $\begin{array}{l}\text { High School } \\
\text { Drop-Outs }\end{array}$ & 0.79 & 0.79 & 0.81 & 0.89 & 0.97 & 0.92 \\
\hline $\begin{array}{l}\text { High School } \\
\text { Graduates }\end{array}$ & 0.51 & 0.51 & 0.56 & 0.61 & 0.67 & 0.64 \\
\hline $\begin{array}{l}\text { Some } \\
\text { College }\end{array}$ & 0.49 & 0.51 & 0.53 & 0.56 & 0.61 & 0.59 \\
\hline $\begin{array}{l}\text { College } \\
\text { Graduates }\end{array}$ & 0.44 & 0.46 & 0.46 & 0.48 & 0.51 & 0.51 \\
\hline
\end{tabular}

\section{${ }^{\mathrm{a}}$ Notes:}

1. Data are from the March Demographic Supplement to the Current Population Survey 1968-2000. Individuals with zero earnings are included in the sample. See Section 3 for other sample inclusion criteria and a description of the wage data. Wages are deflated to 1999 dollars using the Personal Consumption Expenditure Deflator. 


\begin{tabular}{|c|c|c|c|c|c|c|c|c|c|}
\hline \multicolumn{10}{|c|}{$\begin{array}{l}\text { Table } 7^{\text {a }} \\
\text { Decomposition of change in lifetime earnings } \\
\text { into change in wages and change in annual hours } \\
\text { relative to the } 1967-1970 \text { cohort }\end{array}$} \\
\hline & $\begin{array}{l}\text { Year of Entry } \\
\text { into Labor } \\
\text { Market }\end{array}$ & & $\begin{array}{l}\text { (1) } \\
\text { Loss of } \\
\text { lifetime } \\
\text { arnings }\end{array}$ & & $\begin{array}{l}(2) \\
\text { change } \\
\text { change } \\
\text { hourly } \\
\text { wage }\end{array}$ & & $\begin{array}{l}\text { (3) } \\
\text { ss due } \\
\text { change } \\
\text { annual } \\
\text { ours }\end{array}$ & $\begin{array}{l}(4) \\
\text { Proportion } \\
\text { of change } \\
\text { due to } \\
\text { change in } \\
\text { hourly } \\
\text { wage }\end{array}$ & $\begin{array}{l}\text { (5) } \\
\text { Proportion } \\
\text { of change } \\
\text { due to } \\
\text { change in } \\
\text { annual } \\
\text { hours }\end{array}$ \\
\hline \multirow[t]{5}{*}{ All Workers } & $1971-1974$ & $\$$ & 10,020 & $\$$ & 5,780 & $\$$ & 4,240 & 0.58 & 0.42 \\
\hline & $1975-1978$ & & 20,280 & $\$$ & 14,900 & $\$$ & 5,380 & 0.73 & 0.27 \\
\hline & 1979-1982 & & 26,740 & $\$$ & 22,350 & $\$$ & 4,390 & 0.84 & 0.16 \\
\hline & 1983-1986 & & 29,220 & $\$$ & 27,730 & $\$$ & 1,490 & 0.95 & 0.05 \\
\hline & $1987-1990$ & & 28,550 & $\$$ & 29,590 & $\$$ & $-1,040$ & 1.04 & -0.04 \\
\hline \multirow{5}{*}{$\begin{array}{l}\text { High School } \\
\text { Drop-Outs }\end{array}$} & $1971-1974$ & $\$$ & 6,680 & $\$$ & -540 & $\$$ & 7,220 & -0.08 & 1.08 \\
\hline & $1975-1978$ & & 24,100 & $\$$ & 10,440 & & 13,660 & 0.43 & 0.57 \\
\hline & 1979-1982 & & 43,020 & $\$$ & 36,400 & & 16,620 & 0.61 & 0.39 \\
\hline & 1983-1986 & & 46,600 & $\$$ & 30,200 & & 16,390 & 0.65 & 0.35 \\
\hline & $1987-1990$ & & 44,060 & $\$$ & 31,120 & $\$$ & 12,940 & 0.71 & 0.29 \\
\hline \multirow{5}{*}{$\begin{array}{l}\text { High School } \\
\text { Graduates }\end{array}$} & $1971-1974$ & $\$$ & 11,950 & $\$$ & 3,390 & $\$$ & 8,560 & 0.28 & 0.72 \\
\hline & $1975-1978$ & & 27,140 & $\$$ & 17,970 & $\$$ & 9,170 & 0.66 & 0.34 \\
\hline & 1979-1982 & $\$$ & 42,340 & $\$$ & 33,870 & $\$$ & 8,470 & 0.80 & 0.20 \\
\hline & 1983-1986 & $\$$ & 55,700 & $\$$ & 47,750 & $\$$ & 7,950 & 0.86 & 0.14 \\
\hline & $1987-1990$ & $\$$ & 59,300 & $\$$ & 53,240 & $\$$ & 6,070 & 0.90 & 0.10 \\
\hline
\end{tabular}

${ }^{\mathrm{a}}$ Notes:

1. Data are from the March Demographic Supplement to the Current Population Survey 1968-2000. See Section 3 for sample inclusion criteria and a description of the wage data. Wages are deflated to 1999 dollars using the Personal Consumption Expenditure Deflator.

2. For formulas used to calculate the loss due to the change in annual hours and the loss due to the change in hourly wages see Section 6 . Columns may not add due to rounding. 


\begin{tabular}{|c|c|c|c|c|c|c|c|c|c|}
\hline \multicolumn{10}{|c|}{$\begin{array}{c}\text { Table } 7 \text { (cont'd) }^{\mathrm{a}} \\
\text { Decomposition of change in lifetime earnings } \\
\text { into change in wages and change in annual hours } \\
\text { relative to the } 1967-1970 \text { cohort }\end{array}$} \\
\hline & $\begin{array}{c}\text { Year of Entry } \\
\text { into Labor } \\
\text { Market }\end{array}$ & & $\begin{array}{l}\text { (1) } \\
\text { oss of } \\
\text { fetime } \\
\text { irnings }\end{array}$ & & $\begin{array}{l}\text { (2) } \\
\text { ss due } \\
\text { change } \\
\text { hourly } \\
\text { Nage }\end{array}$ & & $\begin{array}{l}\text { (3) } \\
\text { ss due } \\
\text { change } \\
\text { annual } \\
\text { ours }\end{array}$ & $\begin{array}{l}(4) \\
\text { Proportion } \\
\text { of change } \\
\text { due to } \\
\text { change in } \\
\text { hourly } \\
\text { wage }\end{array}$ & $\begin{array}{l}\text { (5) } \\
\text { Proportion } \\
\text { of change } \\
\text { due to } \\
\text { change in } \\
\text { annual } \\
\text { hours }\end{array}$ \\
\hline \multirow{5}{*}{$\begin{array}{l}\text { Some } \\
\text { College }\end{array}$} & $1971-1974$ & $\$$ & 10,160 & $\$$ & 7,910 & $\$$ & 2,250 & 0.78 & 0.22 \\
\hline & $1975-1978$ & $\$$ & 13,680 & $\$$ & 12,250 & $\$$ & 1,430 & 0.90 & 0.10 \\
\hline & 1979-1982 & $\$$ & 19,770 & $\$$ & 21,630 & $\$$ & $-1,860$ & 1.09 & -0.09 \\
\hline & $1983-1986$ & $\$$ & 32,910 & $\$$ & 35,530 & $\$$ & $-2,620$ & 1.08 & -0.08 \\
\hline & $1987-1990$ & $\$$ & 43,350 & $\$$ & 45,810 & $\$$ & $-2,460$ & 1.06 & -0.06 \\
\hline \multirow{5}{*}{$\begin{array}{l}\text { College } \\
\text { Graduates }\end{array}$} & $1971-1974$ & $\$$ & 26,262 & $\$$ & 22,890 & $\$$ & 3,370 & 0.87 & 0.13 \\
\hline & $1975-1978$ & $\$$ & 26,260 & $\$$ & 26,670 & $\$$ & -410 & 1.02 & -0.02 \\
\hline & $1979-1982$ & $\$$ & 4,230 & $\$$ & 5,460 & $\$$ & $-1,230$ & 1.29 & -0.29 \\
\hline & $1983-1986$ & $\$$ & $-1,060$ & $\$$ & 6,690 & $\$$ & $-7,750$ & -6.31 & 7.31 \\
\hline & $1987-1990$ & $\$$ & $-3,040$ & $\$$ & 5,740 & $\$$ & $-8,780$ & -1.89 & 1.89 \\
\hline
\end{tabular}

${ }^{\mathrm{a}}$ Notes:

1. Data are from the March Demographic Supplement to the Current Population Survey 1968-2000. See Section 3 for sample inclusion criteria and a description of the wage data. Wages are deflated to 1999 dollars using the Personal Consumption Expenditure Deflator.

2. For formulas used to calculate the loss due to the change in annual hours and the loss due to the change in hourly wages see Section 6. 


\begin{tabular}{|l|r|r|r|r|}
\hline \multicolumn{7}{|c|}{$\begin{array}{c}\text { Table 8 } \\
\text { Coefficient of variation of ten-year hourly wages } \\
\text { for men with 1 to 10 years of experience }\end{array}$} \\
\hline $\begin{array}{l}\text { Years of Entry } \\
\text { into the Labor } \\
\text { Market }\end{array}$ & $1975-1978$ & \multicolumn{1}{c|}{$1979-1982$} & $1983-1986$ & $1987-1990$ \\
\hline All Workers & 0.32 & 0.33 & 0.35 & 0.34 \\
\hline \hline $\begin{array}{l}\text { High School } \\
\text { Drop-Outs }\end{array}$ & 0.42 & 0.46 & 0.40 & 0.46 \\
\hline $\begin{array}{l}\text { High School } \\
\text { Graduates }\end{array}$ & 0.30 & 0.33 & 0.33 & 0.37 \\
\hline Some College & 0.30 & 0.33 & 0.38 & 0.30 \\
\hline $\begin{array}{l}\text { College } \\
\text { Graduates }\end{array}$ & 0.30 & 0.30 & 0.31 & 0.31 \\
\hline
\end{tabular}

${ }^{\mathrm{a}}$ Notes:

1. Data are from the March Demographic Supplement to the Current Population Survey 1968-2000. Individuals with zero earnings are included in the sample. See Section 3 for other sample inclusion criteria and a description of the wage data. Wages are deflated to 1999 dollars using the Personal Consumption Expenditure Deflator. Section 5 .

2. For formulas used to calculate the variance of ten-year earnings underlying the coefficient of variation see 


\begin{tabular}{|l|r|r|r|r|}
\hline \multicolumn{7}{|c|}{$\begin{array}{c}\text { Table 9 } \\
\text { Coefficient of variation of ten-year total hours worked } \\
\text { for men with 1 to 10 years of experience }\end{array}$} \\
\hline $\begin{array}{l}\text { Years of Entry } \\
\text { into the Labor } \\
\text { Market }\end{array}$ & $1975-1978$ & $1979-1982$ & $1983-1986$ & $1987-1990$ \\
\hline All Workers & 0.20 & 0.21 & 0.20 & 0.19 \\
\hline \hline $\begin{array}{l}\text { High School } \\
\text { Drop-Outs }\end{array}$ & 0.39 & 0.41 & 0.41 & 0.37 \\
\hline $\begin{array}{l}\text { High School } \\
\text { Graduates }\end{array}$ & 0.21 & 0.23 & 0.21 & 0.22 \\
\hline Some College & 0.17 & 0.19 & 0.18 & 0.18 \\
\hline $\begin{array}{l}\text { College } \\
\text { Graduates }\end{array}$ & 0.14 & 0.15 & 0.14 & 0.13 \\
\hline
\end{tabular}

\section{${ }^{\mathrm{a}}$ Notes:}

1. Data are from the March Demographic Supplement to the Current Population Survey 1968-2000. See Section 3 for other sample inclusion criteria and a description of the data.

2. For formulas used to calculate the variance of ten-year earnings underlying the coefficient of variation see Section 5. 


\section{Data Appendix}

This section provides more detail on a few issues discussed in the data section (section 3) of the paper.

\section{A.1 The Matched CPS}

Although the matched CPS has many advantages discussed in the text, the data do have some limitations. First, it is not possible to match the pairs of years 1971/1972, 1972/1973, $1976 / 1977,1985 / 1986$, and 1995/1996 due to changes in the survey design. This means that the sample size of first cohort during years of experience 3 through 6 is somewhat small (of course this affects only the analysis involving the matched data). The second limitation is that because the CPS is a residence based survey, individuals who move between surveys or who fail to respond to the survey in one of the years cannot be matched. Overall, about 75 percent of households can be matched across a pair of years and about 88 percent of individuals in the first survey who are in matched households can be matched.

Based on the above description, it is clear that the probability of being matched is not random. The matched CPS sample tends to be somewhat older and more stable than the overall CPS sample. However, neither the match rates nor the characteristics of those matched change over time so the match process should not affect the trends in which we are interested. Furthermore, the two samples are generally not statistically significantly different from one another with respect to the primary variables of interest in this paper. Appendix Table 1 presents the mean annual wage and salary income and mean hours worked at one and 10 years of experience for each of the 6 large cohort groupings for the matched and unmatched CPS samples. In all but one case (for workers in the $4^{\text {th }}$ cohort with 10 years of experience), the 95 percent confidence intervals for the two samples overlap. 


\section{A.2 Imputing Usual Hours Worked and Weeks Worked.}

The CPS began asking a question on usual hours worked per week in 1976. Therefore the data was imputed using information on hours worked in the week prior to the interview, which is available for the whole time period, as well as information on full-time work status and weeks worked in the year prior to the interview. The weeks worked variable was reported in intervals prior to 1976 . Individuals were assigned to an actual number of weeks using that the weeks interval as well as information on the relationship between number of weeks worked, the number of weeks looking for work in the previous year, and the number of weeks unemployed, in the post-1976 data. 


\begin{tabular}{|c|c|c|c|c|c|c|c|c|c|c|c|c|c|}
\hline \multirow[b]{4}{*}{ Cohort } & \multirow[b]{4}{*}{$\begin{array}{l}\text { Experienc } \\
\mathrm{e}\end{array}$} & \multicolumn{12}{|c|}{$\begin{array}{l}\text { Appendix Table } 1^{\mathrm{a}} \\
\text { Comparison of means of annual wage and salary income and usual hours worked } \\
\text { in the unmatched and matched Current Population Survey data. }\end{array}$} \\
\hline & & \multicolumn{6}{|c|}{ Annual Wage and Salary Income } & \multicolumn{6}{|c|}{ Usual Hours Worked } \\
\hline & & \multicolumn{3}{|c|}{ Unmatched Data } & \multicolumn{3}{|c|}{ Matched Data } & \multicolumn{3}{|c|}{ Unmatched Data } & \multicolumn{3}{|c|}{ Matched Data } \\
\hline & & $\begin{array}{l}\text { Lower } \\
95 \% \text { C.I. }\end{array}$ & Mean & $\begin{array}{c}\text { Upper } \\
95 \% \text { C.I. }\end{array}$ & $\begin{array}{l}\text { Lower } \\
95 \% \\
\text { C.I. }\end{array}$ & Mean & $\begin{array}{c}\text { Upper } \\
95 \% \text { C.I. }\end{array}$ & $\begin{array}{l}\text { Lower } \\
95 \% \\
\text { C.I. }\end{array}$ & Mean & $\begin{array}{l}\text { Upper } \\
95 \% \\
\text { C.I. }\end{array}$ & $\begin{array}{l}\text { Lowe } \\
\quad r \\
95 \% \\
\text { C.I. }\end{array}$ & Mean & $\begin{array}{l}\text { Uppe } \\
\quad r \\
95 \% \\
\text { C.I. }\end{array}$ \\
\hline \multirow[t]{2}{*}{1} & $1^{\text {st }}$ Year & $\$ 17,430$ & $\$ 17,979$ & $\$ 18,528$ & $\$ 17,654$ & $\$ 19,158$ & $\$ 20,662$ & 39 & 39 & 40 & 38 & 39 & 40 \\
\hline & $10^{\text {th }}$ Year & $\$ 33,325$ & $\$ 33,907$ & $\$ 34,488$ & $\$ 33,670$ & $\$ 34,727$ & $\$ 35,784$ & 43 & 44 & 44 & 43 & 44 & 44 \\
\hline \multirow[t]{2}{*}{2} & $1^{\text {st }}$ Year & $\$ 18,273$ & $\$ 18,713$ & $\$ 19,154$ & $\$ 18,067$ & $\$ 19,307$ & $\$ 20,546$ & 40 & 41 & 41 & 40 & 41 & 41 \\
\hline & $10^{\text {th }}$ Year & $\$ 30,944$ & $\$ 31,477$ & $\$ 32,009$ & $\$ 30,763$ & $\$ 31,760$ & $\$ 32,757$ & 42 & 43 & 43 & 42 & 43 & 43 \\
\hline \multirow[t]{2}{*}{3} & $1^{\text {st }}$ Year & $\$ 17,662$ & $\$ 18,074$ & $\$ 18,485$ & $\$ 18,210$ & $\$ 19,317$ & $\$ 20,424$ & 40 & 41 & 41 & 41 & 41 & 42 \\
\hline & $10^{\text {th }}$ Year & $\$ 31,553$ & $\$ 32,143$ & $\$ 32,733$ & $\$ 32,424$ & $\$ 33,778$ & $\$ 35,131$ & 44 & 44 & 44 & 43 & 44 & 44 \\
\hline \multirow[t]{2}{*}{4} & $1^{\text {st }}$ Year & $\$ 17,113$ & $\$ 17,517$ & $\$ 17,920$ & $\$ 16,946$ & $\$ 17,879$ & $\$ 18,811$ & 40 & 40 & 40 & 40 & 41 & 41 \\
\hline & $10^{\text {th }}$ Year & $\$ 30,635$ & $\$ 31,264$ & $\$ 31,893$ & $\$ 32,814$ & $\$ 34,086$ & $\$ 35,357$ & 43 & 43 & 43 & 44 & 45 & 45 \\
\hline \multirow[t]{2}{*}{5} & $1^{\text {st }}$ Year & $\$ 15,385$ & $\$ 15,828$ & $\$ 16,271$ & $\$ 14,289$ & $\$ 15,497$ & $\$ 16,704$ & 39 & 39 & 40 & 38 & 39 & 40 \\
\hline & $10^{\text {th }}$ Year & $\$ 30,362$ & $\$ 31,101$ & $\$ 31,840$ & $\$ 30,872$ & $\$ 32,708$ & $\$ 34,545$ & 44 & 44 & 44 & 44 & 44 & 45 \\
\hline \multirow[t]{2}{*}{6} & $1^{\text {st }}$ Year & $\$ 16,751$ & $\$ 17,281$ & $\$ 17,810$ & $\$ 18,821$ & $\$ 19,967$ & $\$ 21,112$ & 39 & 40 & 40 & 40 & 42 & 43 \\
\hline & $10^{\text {th }}$ Year & $\$ 32,728$ & $\$ 33,604$ & $\$ 34,479$ & $\$ 32,900$ & $\$ 34,995$ & $\$ 37,091$ & 44 & 45 & 45 & 45 & 46 & 46 \\
\hline
\end{tabular}

\section{${ }^{\mathrm{a}}$ Notes:}

1. Data are from the March Demographic Supplement to the Current Population Survey 1968-2000. See Section 2 for sample inclusion criteria and a description of the data. Wages are deflated to 1999 dollars using the Personal Consumption Expenditure Deflator.

2. The matched data are two-year panels in which individuals are linked across adjacent years of the March CPS. See Section 3 for a further description of the data. 